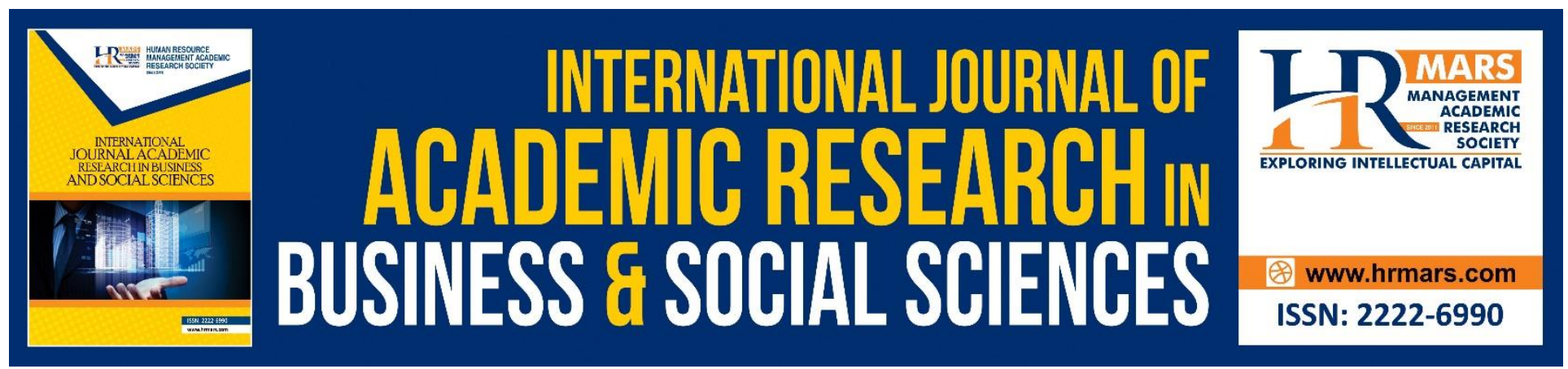

\title{
How does Financial Communication affect Millennials' Online Shares Purchase Intention?
}

Feroz De Costa, Norzalita Abd Aziz, Wan Mohd Hirwani Wan Hussain, Nurul Ain Mohd Hasan

To Link this Article: http://dx.doi.org/10.6007/IJARBSS/v10-i9/7784

DOI:10.6007/IJARBSS/v10-i9/7784

Received: 08 June 2020, Revised: 11 July 2020, Accepted: 15 August 2020

Published Online: 28 September 2020

In-Text Citation: (De Costa, Abd Aziz, Hussain, \& Hasan, 2020).

To Cite this Article: De Costa, F., Abd Aziz, N., Hussain, W. M. H. W., Hasan, N.A. M. (2020). How does Financial Communication affect Millennials' Online Shares Purchase Intention? International Journal of Academic Research in Business and Social Sciences. 10(9), 681-698.

Copyright: (C) 2020 The Author(s)

Published by Human Resource Management Academic Research Society (www.hrmars.com)

This article is published under the Creative Commons Attribution (CC BY 4.0) license. Anyone may reproduce, distribute, translate and create derivative works of this article (for both commercial and non-commercial purposes), subject to full attribution to the original publication and authors. The full terms of this license may be seen at: http://creativecommons.org/licences/by/4.0/legalcode

Vol. 10, No. 9, 2020, Pg. 681 - 698

Full Terms \& Conditions of access and use can be found at http://hrmars.com/index.php/pages/detail/publication-ethics 


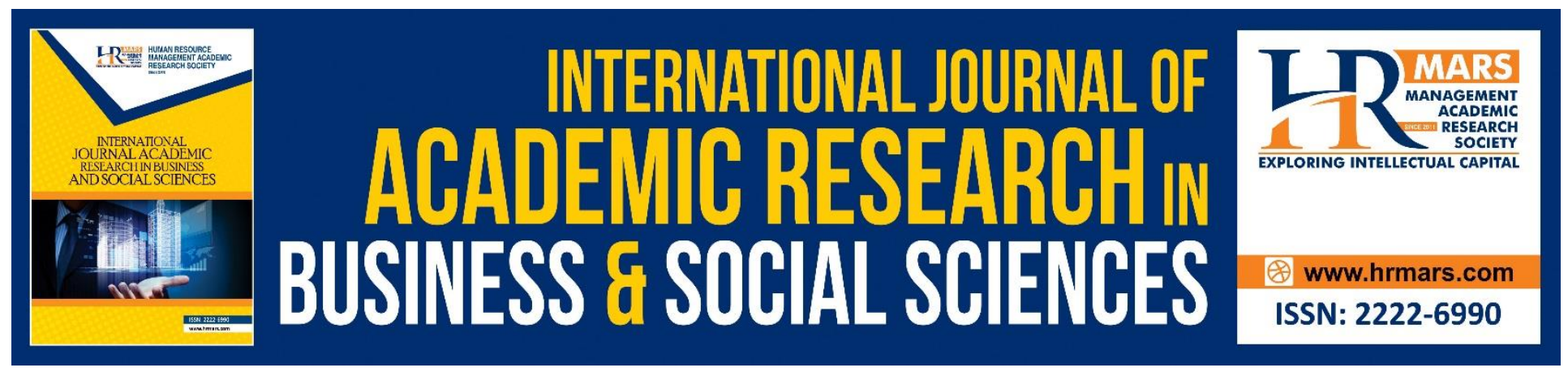

\title{
How does Financial Communication affect Millennials' Online Shares Purchase Intention?
}

\author{
Feroz De Costa \\ Department of Communication, Faculty of Modern Languages and Communication \\ Universiti Putra Malaysia \\ Email: mohdferoz@upm.edu.my
}

\author{
Norzalita Abd Aziz, Wan Mohd Hirwani Wan Hussain \\ UKM-Graduate School of Business \\ Universiti Kebangsaan Malaysia \\ Email: eita@ukm.edu.my,wmhwh@ukm.edu.my
}

\author{
Nurul Ain Mohd Hasan \\ Department of Communication, Faculty of Modern Languages and Communication \\ Universiti Putra Malaysia \\ Email:namh@upm.edu.my
}

\begin{abstract}
The main aim of this article is to identify the influence of online financial communication disseminated through social media on brand attitude and the intention of millennials to purchase Shariah-compliant shares in Malaysia. A convenience sampling procedure using online questionnaires was used to test seven hypotheses based on prior literature. The partial least squares structural equation modelling (PLS-SEM) technique and the SmartPLS 3 tool was used to analyse this study. The findings of this study highlighted that user generated content (UGC) and firm generated content (FGC) positively influence brand attitude. By incorporating the theory of reasoned action and the signalling theory, the result showed a contradictive outcome to previous literature. UGC has no direct effect on the purchase intention of Shariah-compliant online stocks. This study suggests that companies should further comprehend the branding of their companies with the use of their official social media pages by increasing a positive attitude towards their brand.
\end{abstract}

Keywords: Corporate Communication, Financial Communication, Investor Relations, Behavioural Finance, Integrated Marketing Communications, PLS-SEM.

\section{Introduction}

In increasing the purchase intention of online share, it is first vital for corporate communication scholars and practitioners to understand how to manage the openness of communicating with their 
INTERNATIONAL JOURNAL OF ACADEMIC RESEARCH IN BUSINESS AND SOCIAL SCIENCES Vol. 10, No. 9, 2020, E-ISSN: 2222-6990 @ 2020 HRMARS

stakeholders and communicating through social media platforms (Vernuccio, 2014). As global portfolio or investment diversification benefits are beginning to reduce, investors are now forced to pursue safe investment prospects (Antar and Alahouel, 2020). One portfolio that has appealed to international investors in recent years is the development of publicly-traded Shariah-compliant businesses (Al-Yahyaee, Mensi, Rehman, Vo, and Kang, 2020); Saadaoui, 2018), which is within the scope of Islamic finance. Islamic finance is guided by the principles of the Islamic legal system or also known as Shariah law which prohibits interest, excessive risk-taking, gambling, and promotes risksharing instead of risk-shifting which usually exists in conventional financial services and activities. The rise of Islamic finance is further concurred by the report in The Edge Markets (2018) stating that the Association of Islamic Banking and Financial Institutions Malaysia (AIBIM) is assertive to acquire a 40 percent market share in total banking assets by 2020. In another report by the Malaysia International Islamic Financial Centre entitled "Islamic Finance in Asia: Reaching New Heights", stated that Asia's Islamic financial assets are equivalent to US\$528.7 billion or about RM2.05 trillion. This represents 26 percent of the world's Shariah-compliant financial assets as of 2017 (The Malaysian Reserve, 2018). Current statistics are showing that Shariah-compliant securities is becoming more significant whereby 77 percent of the stocks on Bursa Malaysia are Shariah-compliant and the number of Shariah-compliant securities is increasing yearly. A total of 697 companies are listed as Shariah-compliant out of the 900 total companies listed on Bursa Malaysia (Securities Commission Malaysia, 2020).

According to the Department of Statistics Malaysia (2017), the increase in mobile phone usage has led to an increase in online investing among the young generation of investors. With the lower brokerage fees and easy to use online platform to trade shares, Shariah-compliant shares trading is attracting young investors, particularly those between ages of 18 to 25 which are categorized in the millennial group. This millennial online investor group was the fastest-growing age group among Central Depository System (CDS) account holders in 2016, with a total of 27252 account holders as of 30 December 2016, despite being in the age group that has the least amount of wealth. Coming in second were investors between the ages of 26 and 35 which were also within the age group of the millennials (The Star Online, 2017).

Ramazan Yildirim, Mansur Masih and Obiyathulla Ismath Bacha (2018) and Omar Farooq (2016) have discussed the issue of many individual investors from Islamic countries pursue investing only in Shariah-compliant stocks whereby this type of investors is willing to accept the cost of holding a less than efficient portfolio if they obtain more utility from holding assets that adhere to their social or faith-based norms (Almansour and Ongena, 2018; Saadaoui, 2018). In order to meet this increasing demand for Shariah-compliant shares, corporations are now aggressively competing in disseminating online financial communication through social media to attract millennial investors. Behboudi et al. (2014) also indicated that the effectiveness of employing advertising appeals is well-recognized and marketers utilize them for transferring specific information to their customers to attract consumers and impress their thoughts and feelings about a particular product or service. As communication is considered as a crucial factor in influencing customers' behaviour especially when choosing financial products and services, this study focuses on the effect of social media as a communications channel, in particular, user generated content (UGC) and firm generated content (FGC) that influences millennial individual investors.

This study contributes to the theory of reasoned action, signalling theory, and has practical implications. Investor relation and marketing managers of public listed companies are able to 
INTERNATIONAL JOURNAL OF ACADEMIC RESEARCH IN BUSINESS AND SOCIAL SCIENCES Vol. 10, No. 9, 2020, E-ISSN: 2222-6990 @ 2020 HRMARS

comprehend the branding of their companies with the use of their official social media pages. The recent increase of millennial investors and financial communication using social media will certainly influence their attitude towards the advertised brand that is described as the inventors' affective reaction to the advertised brand. The question raised in this study is whether UGC and FGC would have a higher influence on millennial investors' brand attitude and the purchase intention of online shares? Hence, the objective of this study is to identify the influence of online financial communication disseminated through social media on brand attitude and the intention of millennials to purchase Shariah-compliant shares in Malaysia.

\section{Literature Review}

\section{Theory of Reasoned Action}

Ajzen and Fishbein (1980) have discussed the theory of reasoned action tackling disapprovals of rational choice explanations of consumer behaviour by suggesting that individuals are rational in using information available to them and recognized the role of social influence on this rationality. This study used the brand attitude (attitude) construct that will influence millennials' purchase intention (behavioural intention) of Shariah-compliant shares. Studies within the social psychology environment have referenced and used the theory of reasoned action to predict and understand motivational influences on behaviour. Many researches have actually applied the theory of reasoned action such as predicting unethical behaviour in the digital world (Chang, 1998), online grocery buying intention (Hansen, Jensen, and Solgaard, 2004), the use of information technology (Moore and Benbasat 1996) and even research on the use of coupons from the 1980s (Shimp and Kavas, 1984). Research such as these provide extensive empirical support but the results of influence are still varied.

\section{Signalling Theory}

This study also incorporated the signalling theory. Spence (2002) explains signalling theory as to essentially decrease the information asymmetry among two parties. Some studies also illustrated the effects of top managements' financial messages toward their investors. Researchers used signalling theory to rationalize the way companies use varied methods to communicate with their stakeholders (Miller and Triana, 2009). The internet creates a lot of asymmetric information as there will be an abundance of asymmetries information communicated between a supplier and a demander. Even though earlier findings have stated that a sharing economy reputational rating system can function as a form of self-regulation, biases are still guaranteed to occur. Wang (2018) used signalling theory as a conceptual framework in order to research the influence of the information disclosure of mentors on the growth of consulting services. Therefore, based on the relevance of prior studies in using signalling theory in explaining the signalling idea, this study adapted the signalling theory to further explain millennial individual investors' purchase intention of Shariah-compliant shares.

\section{Financial Communication and Millennials}

Financial communication plays an important role in increasing the purchase intention of online shares. Hence, this research admits that corporate leaders, especially the chief executive officers, chief financial officers, and the chairmen should communicate convincingly to their investors (Palmieri \& Palmieri, 2012; Palmieri, Perrin, \& Whitehouse, 2018). Financial communication is defined as "the set of actions in communication concerning all potential investors and their consultants" 
INTERNATIONAL JOURNAL OF ACADEMIC RESEARCH IN BUSINESS AND SOCIAL SCIENCES Vol. 10, No. 9, 2020, E-ISSN: 2222-6990 @ 2020 HRMARS

(Demont et al., 2000). Another definition of Financial Communication is by Wang (2013), where he defined financial communication as "to any kind of communication that conveys messages regarding financial dealings and topics". Wang (2013) further elaborated that financial communication is considered to be a particular investment brochure such as a financial disclosure. Behavioural finance models are usually developed to explain investor behaviour or market anomalies when rational models provide no sufficient explanations" Glaser et al. (2004, p. 527). Muradoglu and Harvey (2012) explained that more interdisciplinary studies are being researched where there are more collaborations between finance, sociology (social interaction) and now in even in marketing perspectives.

Another unique feature of this study is that this study focuses on millennial investors. The millennial generation is selected for this study because this generation always associates themselves with social finance, which is relevant to this study that considers socially responsible investing or Shariah-compliant funds. Cooper et al. (2016) explained that the millennial generation are generally more concerned about social responsibility when they evaluate their personal investments as compared to baby boomers whereby baby boomers are expected to transfer more than $\$ 30$ trillion to the younger generation. Millennial consumers are the largest consumer groups relating to social cause and they make sustainability-based decisions and this generation have strong social consciousness (Formankova et al., 2019; Miller et al., 2017).

\section{User Generated Content and Firm Generated Content}

The Internet has indeed innovated the trend of corporate communication through social media in this fast-moving digital landscape (Argenti \& Barnes, 2009). Online communication will strengthen the prominence of customer engagement methods. Corporations are presently recognizing how important engagement using online communication could ultimately be a more strategic tactic in reinforcing their relationships with their stakeholders. Kietzmann et al. (2011) defined social media as one that employs mobile and web-based technologies to create highly interactive platforms via which individuals and communities share, co-create, discuss, and modify UGC. Even organizations are progressively focusing on marketing communication via online platforms. UGC is focused on online information developed by the public users and not by the companies themselves (Daugherty, Eastin, and Bright, 2008) and interconnected with social media marketing (VanMeter, Grisaffe, and Chonko, 2015; Hudson et al. 2014, 2015).

UGC depicts an assortment of news sources of online information which can be created, initiated, circulated or even used by consumers. UGC is also called electronic word - of - mouth that works exactly like a common word-of-mouth (Manap and Adzharudin, 2013). It is mainly used on educating each other about a certain product, brand, service or even an issue. FGC on the other hand as described by Kumar et al. (2016) is the messages that are posted by companies on their official social media pages. Communication and advertising on social media platforms whether in the form of logos, verbal, pictorial content, graphics or even texts are generally suggested to be part of their branding (Salleh et al., 2016). Therefore, this study examines the influence of UGC and FGC towards millennials' brand attitude and purchase intention.

$\mathrm{H}_{1}$ : UGC will positively affect brand attitude.

$\mathrm{H}_{2}$ : FGC will positively affect brand attitude.

$\mathrm{H}_{3}$ : UGC will positively affect purchase intention. 
INTERNATIONAL JOURNAL OF ACADEMIC RESEARCH IN BUSINESS AND SOCIAL SCIENCES

Vol. 10, No. 9, 2020, E-ISSN: 2222-6990 @ 2020 HRMARS

$\mathrm{H}_{4}$ : FGC will positively affect purchase intention.

\section{Brand Attitude}

Ajzen and Fishbein (1980) explain that the attitude model states that the entire evaluation of brands is the effect of the beliefs regarding the brand itself. Brand attitude has been clarified by way of customers' whole evaluation of a specific brand (Olson and Mitchell, 1981). Relevant research such as by Keller and Lehmann (2006) has stated that when customers have a positive attitude toward a brand, then it will positively influence their purchase intention. Han and Guo (2018) indicated that the young generation or millennials always relate to certain brands and there are several studies that looked into this where their respondents are reasonably familiar with known brands whereby these values are becoming common among the millennial generation. In another study, Venter de Villiers, Visnenza, and Phiri (2017) explained that millennials are the most relevant generation to be examined in research that focuses on brand and purchase intention.

The reason why Brand Attitude is being studied as a mediator in this study is to heighten the importance of the social media platforms as a communication and information medium for customer brands and definitely current investors which would eventually affect stocks purchase intention. Customers are progressively dynamic members in interactive online real-time communication (Prahalad and Ramaswamy, 2004). Based on these studies, social benefits are considered to be the most important criteria to customers and that is why this study is stressing the interactive customer engagement concept with brands via UGC and FGC. There were studies inspecting firm-hosted online communities where consumers interactively participate in assisting each other to resolve issues. This shows that people interact with people whom they have never met offline and they even perceived the informational value of interacting with the community (Wiertz and de Ruyter, 2007). This is related to UGC because customers who feel close to a specific brand will eventually be encouraged to spread positive word of mouth (Albert and Valette-Florence, 2009).

Chauhan and Pillai (2013) identified that the brand community is very beneficial for a company in building a strong brand presence. Su and Hsu (2013) stated that customer emotions can also be a mediator for the relationship of staff friendliness and the motivation to buy and spread word of mouth. Therefore, this study concludes that it is sensible to expect that brand attitude can be a mediator for online generated content and purchase intention because brand affection or brand connection or better known as brand attitude in this study will affect purchase intention. This will result in increased purchase intention of the goods or services. Therefore, this study investigates the suitability of brand attitude to be selected as the mediator between UGC and FGC towards the purchase intention of Shariah-compliant online stocks.

$\mathrm{H}_{5}$ : Brand attitude will positively affect purchase intention.

$\mathrm{H}_{6}$ : Brand attitude will mediate the relationship between UGC and purchase intention.

$\mathrm{H}_{7}$ : Brand attitude will mediate the relationship between FGC and purchase intention.

Based on the literature discussed, Figure 1 shows the model of this paper. FGC has 4 items that were based on Schivinski and Dabrowski (2014). There are seven items for the UGC construct which was based on the study of Hazari, Bergiel, and Sethna (2017) and brand attitude has four items that were adapted from Lee (2017). Lastly, purchase intention has 3 items that were adapted from Li, Fu, and Huang (2015). 
INTERNATIONAL JOURNAL OF ACADEMIC RESEARCH IN BUSINESS AND SOCIAL SCIENCES Vol. 10, No. 9, 2020, E-ISSN: 2222-6990 @ 2020 HRMARS

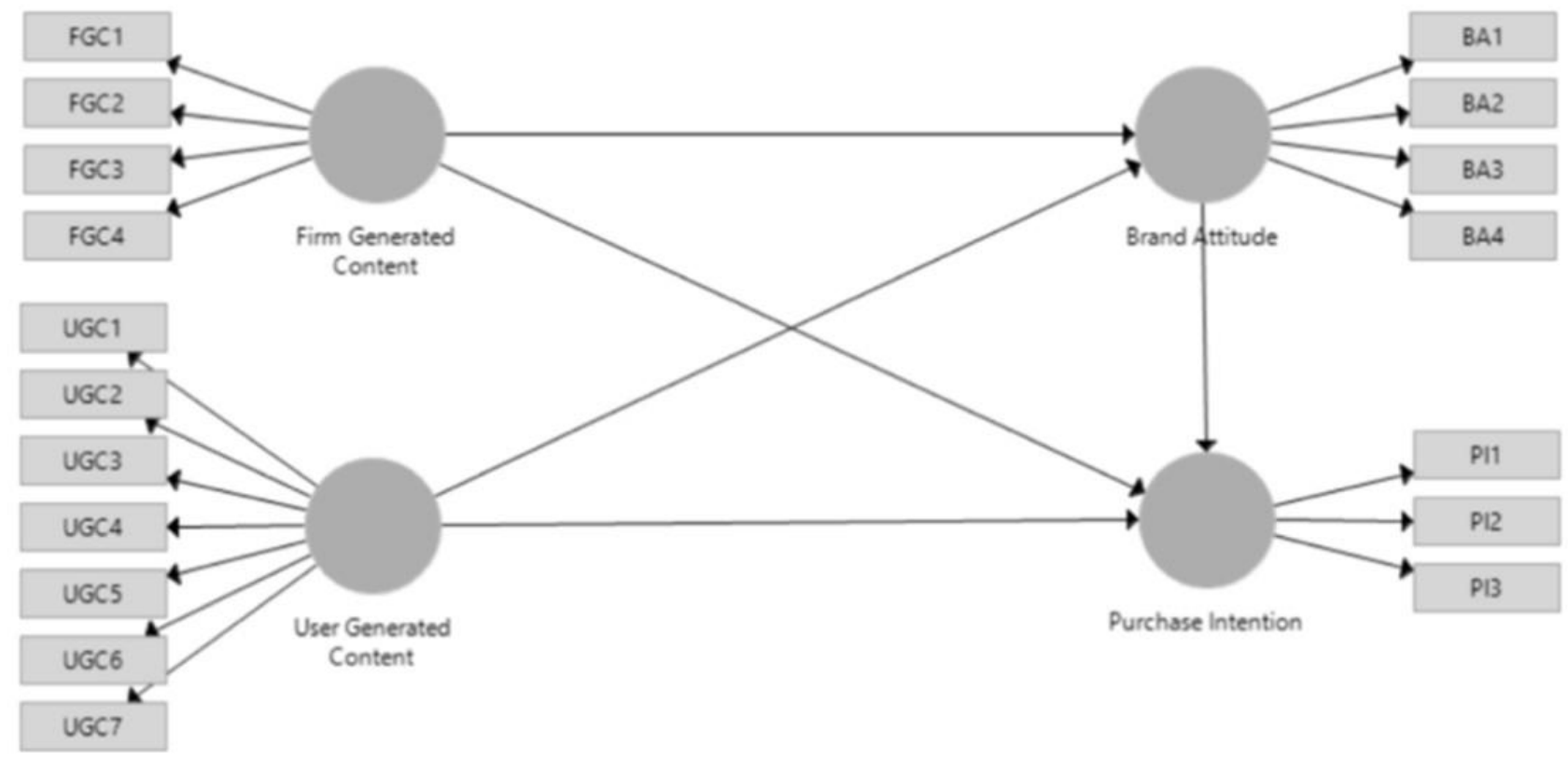

Figure 1: Research Model

\section{Research Methodology}

The unit of analysis for this study is individual investors. This research analysed potential individual investors who are also categorized as millennials. As defined by Strauss and Howe (1991) the millennial Generation or also called Generation Y are those born between the year of 1982 to 2000. This study used convenience sampling method as suggested by Hulland et al. (2017). All of the statements are basically formed according to the latent construct of this research. These statements are formatted based on previous studies and were distributed first as a pre-test and a pilot study to 120 respondents to test the suitability of the statements for our context here in Malaysia and some modification were made to the final data after the pre-test and even after the pilot study.

This study used the intercept surveys method or by personally approaching all the respondents using mobile phones and tablets and politely requesting them to answer the survey during the Bursa Malaysia Investing Fair. Out of the 340 completed questionnaires received, only about 9 percent out of the total replies collected were removed while others were considered to comply and deemed valid.

Table 1 presents the profile of the respondents. This study received higher male participants which represent almost 57 percent of the total number of respondents, as compared to 133 female respondents which were all from the millennial generation from the age of 18 to 35 in 2017 . Although more than 70 percent of the participants had at least a bachelor degree or higher education qualification, the majority of these potential investors or more than 60 percent of them did not have any investment knowledge at all or even held any positions requiring financial expertise within the last 5 years. 
INTERNATIONAL JOURNAL OF ACADEMIC RESEARCH IN BUSINESS AND SOCIAL SCIENCES

Vol. 10, No. 9, 2020, E-ISSN: 2222-6990 @ 2020 HRMARS

Table 1: Profile of respondents

\begin{tabular}{lll}
\hline Characteristics & Frequency & Percentage \% \\
\hline Gender & 175 & 56.8 \\
Male & 133 & 43.2 \\
Female & & \\
Marital status & 210 & 68.2 \\
Single & 98 & 31.8 \\
Married & & \\
Monthly income & 185 & 60.1 \\
RM3,860 and below & 95 & 30.8 \\
RM3,861 - RM8,319 & 28 & 9.1 \\
RM 8,320 and above & & \\
Education level & 157 & 51.0 \\
Bachelor degree & 59 & 19.2 \\
Master degree & 56 & 18.2 \\
Diploma & 26 & 8.4 \\
SPM/STPM & 10 & 3.2 \\
Ph.D. & & \\
Held position requiring financial expertise & 220 & 71.4 \\
No & 88 & 28.6 \\
Yes & & \\
Investment knowledge & 192 & 62.3 \\
None & 59 & 19.2 \\
Very little & 57 & 18.5 \\
Good & &
\end{tabular}

\section{Data Analysis}

This study has selected SmartPLS 3 to forecast key target constructs. This study used PLS-SEM to analyse the specified path model. SmartPLS 3 was used as the tool to run this technique.

According to Hair et al. (2017), it is noted that indicators will only need to be removed if the outer loadings are lower than $\mathbf{0 . 4 0}$. In order to establish the discriminant validity for this study, the square root of AVE of every latent variable ought to be bigger than the latent variable correlations. Table 2 confirms the construct validity (Hair et al., 2017). Next, this study measured convergent validity that is the average variance extracted (AVE) and the discriminant validity which all are required to be checked. This study first ensured that all composite reliability should be higher than 0.7 and the AVE minimum value is 0.5 (Hair et al., 2017). The loading, composite reliability and the AVE for this study are all higher than the recommended values as shown in Table 3. 
INTERNATIONAL JOURNAL OF ACADEMIC RESEARCH IN BUSINESS AND SOCIAL SCIENCES Vol. 10, No. 9, 2020, E-ISSN: 2222-6990 @ 2020 HRMARS

Table 2: Loadings and cross loadings

\begin{tabular}{lllll}
\hline Item & $\begin{array}{l}\text { Brand } \\
\text { Attitude }\end{array}$ & FGC & $\begin{array}{l}\text { Purchase } \\
\text { Intention }\end{array}$ & UGC \\
\hline BA1 & $\mathbf{0 . 8 3 7}$ & 0.637 & 0.556 & 0.689 \\
BA2 & $\mathbf{0 . 8 7 4}$ & 0.663 & 0.800 & 0.644 \\
BA3 & $\mathbf{0 . 8 4 1}$ & 0.655 & 0.577 & 0.594 \\
BA4 & $\mathbf{0 . 8 2 3}$ & 0.590 & 0.604 & 0.668 \\
FGC1 & 0.691 & $\mathbf{0 . 8 5 0}$ & 0.500 & 0.655 \\
FGC2 & 0.543 & $\mathbf{0 . 8 2 7}$ & 0.491 & 0.537 \\
FGC3 & 0.572 & $\mathbf{0 . 7 8 4}$ & 0.557 & 0.501 \\
FGC4 & 0.680 & $\mathbf{0 . 8 5 7}$ & 0.544 & 0.649 \\
PI1 & 0.733 & 0.570 & $\mathbf{0 . 9 0 0}$ & 0.529 \\
PI2 & 0.640 & 0.566 & $\mathbf{0 . 8 7 2}$ & 0.484 \\
PI3 & 0.632 & 0.535 & $\mathbf{0 . 8 7 9}$ & 0.489 \\
UGC1 & 0.674 & 0.614 & 0.445 & $\mathbf{0 . 8 4 5}$ \\
UGC2 & 0.583 & 0.513 & 0.374 & $\mathbf{0 . 7 7 6}$ \\
UGC3 & 0.606 & 0.583 & 0.431 & $\mathbf{0 . 8 6 7}$ \\
UGC4 & 0.535 & 0.523 & 0.407 & $\mathbf{0 . 7 0 9}$ \\
UGC5 & 0.705 & 0.653 & 0.599 & $\mathbf{0 . 7 4 4}$ \\
UGC6 & 0.556 & 0.503 & 0.417 & $\mathbf{0 . 7 2 8}$ \\
UGC7 & 0.491 & 0.444 & 0.380 & .
\end{tabular}

Note: Bold values are loadings for items which are above the recommended value of 0.5 
INTERNATIONAL JOURNAL OF ACADEMIC RESEARCH IN BUSINESS AND SOCIAL SCIENCES Vol. 10, No. 9, 2020, E-ISSN: 2222-6990 @ 2020 HRMARS

Table 3: Measurement model results

\begin{tabular}{lllll}
\hline Model Construct & $\begin{array}{l}\text { Measurement } \\
\text { Item }\end{array}$ & Loading & CR & AVE \\
\hline Brand attitude & BA1 & 0.837 & 0.908 & 0.713 \\
& BA2 & 0.874 & & \\
& BA3 & 0.841 & & \\
FGC & BA4 & 0.823 & & \\
& FGC1 & 0.850 & 0.898 & 0.689 \\
& FGC2 & 0.827 & & \\
Purchase intention & FGC3 & 0.784 & & \\
& FGC4 & 0.857 & & 0.782 \\
& PI1 & 0.900 & 0.915 & \\
UGC & PI3 & 0.872 & & \\
& UGC1 & 0.879 & & \\
& UGC2 & 0.845 & 0.917 & \\
& UGC3 & 0.776 & & \\
& UGC4 & 0.867 & & \\
& UGC5 & 0.744 & & \\
& UGC6 & 0.804 & & \\
& UGC7 & 0.728 & & \\
\hline
\end{tabular}

Notes: $\mathrm{CR}$ = composite reliability; $\mathrm{AVE}$ = average variance extracted

Conferring to the study of Chin (1998) and Snell and Dean (1992), cross-loading of below 0.1 should be deleted or could also consider using highly correlated constructs to develop Hierarchical Component Model or Higher Order Construct (HOC) that is recognized as the second-order construct.

One of the newest SmartPLS-SEM requirements since 2017 is the HTMT criterion. According to Gold et al. (2001), discriminant validity is established for the construct when the HTMT criterion results are less than 0.90 . In Table 4 of the HTMT criterion results, all of the results showed below the 0.90 threshold. It is important to note that if the HTMT results were higher, there are several approaches that could be taken into consideration such as deleting or merging the indicators as suggested by Ramayah et al. (2018).

Table 4: HTMT

Brand Attitude FGC $\quad \begin{aligned} & \text { Purchase } \\ & \text { Intention UGC }\end{aligned}$

\begin{tabular}{llll}
\hline Brand Attitude & & & \\
FGC & 0.874 & & \\
Purchase Intention & 0.867 & 0.737 & \\
UGC & 0.861 & 0.798 & 0.634 \\
\hline
\end{tabular}


INTERNATIONAL JOURNAL OF ACADEMIC RESEARCH IN BUSINESS AND SOCIAL SCIENCES Vol. 10, No. 9, 2020, E-ISSN: 2222-6990 @ 2020 HRMARS

\section{Results}

The structural model must be accurately assessed before coming out with any conclusions. Before the structural model was evaluated, it is vital to ensure that there is no lateral collinearity issue in the structural model. The structural model was then assessed using PLS Algorithm in order to get the coefficient of determination $\left(R^{2}\right)$. The $R^{2}$ of 0.677 (Band attitude) and 0.587 (Purchase intention) as shown in Table 5 is above the value of 0.26 and 0.67 as suggested by Chin (1998) and Cohen (1988) respectively that indicates a substantial coefficient of determination. This study also took note that the $\mathrm{R}^{2}$ values of 0.20 are actually considered high in the areas of research such as consumer behaviour (Hair, Ringle, and Sarstedt, 2011) such as this study.

The $R^{2}$ for the purchase intention is 0.587 , indicating that 58.7 percent of the variance in the extent of purchase intention can be explained by UGC, FGC and brand attitude. From examining the results in Table 5 (Direct relationships), it is clearly shown that six out of seven hypotheses are supported and significant at $\mathrm{p}<0.01(\mathrm{H} 1, \mathrm{H} 2, \mathrm{H} 4$, and $\mathrm{H} 5)$, with the beta value of 0.469 for $\mathrm{H} 1,0.421$ for $\mathrm{H} 2$, for $0.163 \mathrm{H} 4$ and 0.704 for $\mathrm{H} 5$. $\mathrm{H} 3$ is not supported because previous literature hypothesized a positive relationship whereas the PLS result showed a negative relationship and moreover the $t$ value was not significant.

As suggested by Cohen (1988), the values of $0.02,0.15$ and 0.35 represent that the effect sizes are small, medium and large. By looking at Table 5, the results indicated that UGC (0.339) has a large effect in producing the $R^{2}$ for brand attitude. FGC (0.273) contributed a medium effect in producing the $R^{2}$ of brand attitude. In terms of producing the $R^{2}$ for purchase intention, brand attitude (0.387) had the largest impact in producing the $R^{2}$ for purchase intention while FGC $(0.025)$ only had a small effect in producing the $R^{2}$ for purchase intention. Lastly, UGC $(0.007)$ had no effects in producing the $R^{2}$ for purchase intention as the $t$-value was not even significant.

Table 5: Hypotheses testing for direct relationships

\begin{tabular}{|c|c|c|c|c|c|c|c|c|c|}
\hline $\begin{array}{l}\text { Hypothesi } \\
\text { s }\end{array}$ & Relationship & & $\begin{array}{l}\text { Std. } \\
\text { Beta }\end{array}$ & $\begin{array}{l}\text { Std. } \\
\text { Error }\end{array}$ & $t$-value & Decision & $R^{2}$ & $f^{2}$ & $Q^{2}$ \\
\hline $\mathrm{H} 1$ & UGC -> Bran & ttitude & $\begin{array}{l}0.46 \\
9\end{array}$ & 0.048 & $9.799 * *$ & Supported & $\begin{array}{l}0.67 \\
7\end{array}$ & $\begin{array}{l}0.33 \\
9\end{array}$ & $\begin{array}{l}0.46 \\
3\end{array}$ \\
\hline $\mathrm{H} 2$ & FGC $->$ Branc & ttitude & $\begin{array}{l}0.42 \\
1\end{array}$ & 0.049 & $8.629 * *$ & Supported & $\begin{array}{l}0.67 \\
7\end{array}$ & $\begin{array}{l}0.27 \\
3\end{array}$ & $\begin{array}{l}0.46 \\
3\end{array}$ \\
\hline H3 & $\begin{array}{l}\text { UGC -> } \\
\text { intention }\end{array}$ & Purchase & $\begin{array}{l}- \\
0.08 \\
9\end{array}$ & 0.059 & 1.505 & $\begin{array}{l}\text { Not } \\
\text { Supported }\end{array}$ & $\begin{array}{l}0.58 \\
7\end{array}$ & $\begin{array}{l}0.00 \\
7\end{array}$ & $\begin{array}{l}0.43 \\
7\end{array}$ \\
\hline $\mathrm{H} 4$ & $\begin{array}{l}\text { FGC } \quad-> \\
\text { intention }\end{array}$ & Purchase & $\begin{array}{l}0.16 \\
3\end{array}$ & 0.060 & $2.700 * *$ & Supported & $\begin{array}{l}0.58 \\
7\end{array}$ & $\begin{array}{l}0.02 \\
5\end{array}$ & $\begin{array}{l}0.43 \\
7\end{array}$ \\
\hline H5 & $\begin{array}{l}\text { Brand at } \\
\text { Purchase int }\end{array}$ & $\begin{array}{l}\text { ude } \quad-> \\
\text { tion }\end{array}$ & $\begin{array}{l}0.70 \\
4\end{array}$ & 0.063 & $11.140 * *$ & Supported & $\begin{array}{l}0.58 \\
7\end{array}$ & $\begin{array}{l}0.38 \\
7\end{array}$ & $\begin{array}{l}0.43 \\
7\end{array}$ \\
\hline
\end{tabular}

Notes: ${ }^{*} p<0.05,{ }^{*} p<0.01, * * * p<0.10$,

$: f^{2}: 0.02$, small; 0.15 , medium; 0.35 , large

When the value of $Q^{2}$ is larger than 0 , it shows that the model has a good predictive relevance (Chin, 1998). As based on Hair et al. (2017), the relative measure of predictive relevance of $0.02,0.15$ and 0.35 represents that the exogenous construct has a small, medium and large predictive relevance 
INTERNATIONAL JOURNAL OF ACADEMIC RESEARCH IN BUSINESS AND SOCIAL SCIENCES Vol. 10, No. 9, 2020, E-ISSN: 2222-6990 @ 2020 HRMARS

for the particular endogenous construct. Table 5 displays the $Q^{2}$ of 0.463 (Brand attitude) and 0.437 (Purchase intention) which shows a large predictive relevance for both the constructs.

Based on results (Indirect relationships) presented in Table 6, the bootstrapping analysis of this study revealed that the indirect effect $\beta=0.330$ and $\beta=0.296$ are significant with a $t$-value of 7.130 and 7.194. Thus, according to Preacher and Hayes (2008) the indirect effects at 95 percent Bootstrapping Confidence Level Bias Corrected (BC): [LL=0.245, UL $=0.427$ ], [ $\mathrm{LL}=0.218, \mathrm{UL}=0.380$ ] does not straddle a $\mathrm{O}$ in between indicating there is a mediation. $\mathrm{H} 6$ and $\mathrm{H} 7$ do not straddle a 0 in between. Therefore, this study can concretely conclude that the mediation effects are statistically significant for $\mathrm{H} 6$ and $\mathrm{H} 7$.

Table 6: Hypotheses testing for indirect relationships

\begin{tabular}{|c|c|c|c|c|c|c|c|}
\hline \multirow[t]{2}{*}{ Hypothesis } & \multirow[t]{2}{*}{ Relationship } & \multirow{2}{*}{$\begin{array}{l}\text { Std. } \\
\text { Beta }\end{array}$} & \multirow{2}{*}{$\begin{array}{l}\text { Std. } \\
\text { Error }\end{array}$} & \multirow[t]{2}{*}{$t$-value } & \multicolumn{2}{|c|}{$\begin{array}{l}\text { Confidence } \\
\text { Level (BC) }\end{array}$} & \multirow[t]{2}{*}{ Decision } \\
\hline & & & & & LL & UL & \\
\hline $\mathrm{H} 6$ & $\begin{array}{l}\text { UGC } \rightarrow \text { Brand attitude } \rightarrow \\
\text { Purchase intention }\end{array}$ & 0.330 & 0.046 & $7.130 * *$ & 0.245 & 0.427 & Supported \\
\hline $\mathrm{H7}$ & $\begin{array}{l}\text { FGC } \rightarrow \text { Brand attitude } \rightarrow \\
\text { Purchase intention }\end{array}$ & 0.296 & 0.041 & $7.194^{* *}$ & 0.218 & 0.380 & Supported \\
\hline
\end{tabular}

Note: ${ }^{*} p<0.05,{ }^{*} p<0.01, B C=$ Bias Corrected, $U L=$ Upper level, $L L=$ Lower Level

\section{Discussion}

The objective of this study is to identify the influence of online financial communication disseminated through social media on brand attitude and the intention of millennials to purchase Shariahcompliant shares in Malaysia. By looking at the findings of Hypothesis 1 and Hypothesis 2 testing, it shows that UGC and FGC have significant positive effects on millennials' brand attitude of Shariahcompliant-shares. This study shows that the potential millennial investors in Malaysia are influenced by UGC and FGC just as the study of Blankespoor (2018) that found that media influence increases the trading volume. This shows that UGC or comments that are created by the general public and messages posted by corporations in their official social media pages can easily affect potential millennial investors' favourable attitude towards the company's brand of the Shariah-compliant shares. Corporations should therefore be more creative in disseminating online financial communication. In return, when online financial communication is effectively used as a tool, companies will witness the advantages in terms of share price increase. Furthermore, it is concerned not only with matters of brand attitude and the cultivation of a favourable financial and investment environment but also with legal interpretation (Vallen, 2014).

Hypothesis 3 displays a unique discovery that is contradictive to previous literature. The result of Hypothesis 3 testing suggests that UGC has either no direct effect or a very weak negative influence on the purchase intention of Shariah-compliant online stocks. This result denotes that Malaysian millennial investors do not essentially have the intention to purchase online Shariah-compliant shares solely due to the online opinions of other investors. This also suggests that opinions of other investors on social media is not as important to potential investors as compared to information published on 
INTERNATIONAL JOURNAL OF ACADEMIC RESEARCH IN BUSINESS AND SOCIAL SCIENCES Vol. 10, No. 9, 2020, E-ISSN: 2222-6990 @ 2020 HRMARS

the companies' official social media platforms when deciding to purchase an online stock. Both Hypothesis 4 and Hypothesis 5 testing results state that FGC and brand attitude have a direct influence on the purchase intention of Shariah-compliant stocks. Hence, FGC and brand attitude will increase the purchase intention of Shariah-compliant online shares. Therefore, corporations should be using their official social media platforms and their brand presence more strategically to reinforce their brand relationships with millennial investors in Malaysia.

Most importantly, this study displays that brand attitude will significantly mediate the relationships of UGC and FGC towards the purchase intention of Shariah-compliant stocks based on the testing results of Hypothesis 6 and Hypothesis 7. Moreover, this study's results show that by having interactive UGC and FGC initiatives will then lead to purchase intention of Shariah-compliant online stocks via brand attitude, which also coincides to the study by Bowden (2009b). This study is also aligned with the research of Li and Bernoff (2011) and Chu and Kim (2011), whereby corporations are now focusing on developing a two-way communication via the social networking sites to strengthen relationships with consumers and investors. Accordingly, corporations should be monitoring and managing their social media platforms constantly to encourage positive and favourable brand attitude and this will significantly increase the purchase intention of their online shares. The relationship of brand attitude with UGC and FGC is the most significant sign of advertising effectiveness in terms of increasing potential investors' purchase intention of online stocks. This study relates to the study of Praditbatuga (2018), Reiter and Connell (2017) and Amaro, Andreu and Huang (2017) in understanding on how to intensify the purchase intention mainly with the use of technology and social networking sites as a potential mechanism for increasing knowledge of and favourable attitudes.

The theory of reasoned action is used as the main theory for this study followed by the signalling theory. A few researchers have discussed financial behaviours using signalling theory; however, very limited studies have been steered using these two theories in trying to explain how potential investors behave (Gao, Yu, and Cannella, 2016; Wang ,2018). This study adapts these two theories and extends this theory by integrating them in the financial communication perspective. This study developed a logic to further understand the phenomenon that seems inconsistent with a theory (Knott, 2003; Sanders, and Hambrick, 2007), which is why this study used brand attitude as a mediator to explain the entire phenomenon. This research has introduced the influence of online generated content that includes UGC and FGC which explains how their relationships relate to the established constructs in the theory of reasoned action that affects Malaysian millennials investors' purchase intention of Shariah-compliant online shares.

In terms of practical and managerial contributions, this study shows the importance of online generated content in increasing purchase intention of Shariah-compliant online shares. Investor relation and marketing managers should, therefore, choose and design their financial communication more effectively to increase the purchase intention of Shariah-compliant shares. This study allows companies to further comprehend the branding of their companies with the use of their official social media pages through increasing positive attitude towards their brand. This study also confirms that there is a need for millennial investors to be more financial literate in order for them to comprehend the abundance of online financial communication to ensure that they make good investment decisions, especially when deciding to purchase online shares.

This study has several limitations. This research is limited to Malaysian millennial individuals that are social media savvy and are capable of using social media platforms. These individuals are 
INTERNATIONAL JOURNAL OF ACADEMIC RESEARCH IN BUSINESS AND SOCIAL SCIENCES Vol. 10, No. 9, 2020, E-ISSN: 2222-6990 @ 2020 HRMARS

only potential Malaysian millennial investors that have not traded Shariah-compliant online stocks but have the intention to purchase Shariah-compliant online stocks and attended the Shariah Investing Fair 2017. This study mainly has two delimitations or boundaries for FGC. This study only included news or messages announced by firms on their official social media accounts or pages and not by third parties such as a financial analyst. This is to avoid any other financial communications manipulations from third-party media sources. FGC also does not include internal communication or the communication within the companies which are not announced or publicized to the public or potential investors specifically.

\section{Conclusion}

Islamic finance and Islamic marketing have emerged as one of the most rapidly expanding sectors of the global financial industry. This paper provides some contribution to the body of knowledge in relevance to signalling theory, financial communication and integrated marketing communications. Furthermore, the significant evidences within this research provide a foundation for future research in Shariah-compliant capital markets globally. This article exhibits the importance of positive brand attitude formation that will influence investors' perceptions. UGC and FGC strategies should be applied by companies carefully to strengthen investor commitment. It is vital for public listed companies to promote their company brand by posting positive financial news and financial disclosure via FGC. This assignment will ultimately encourage more investors to share their positive views through UGC which will then help these companies to increase their share prices and overall value in the long run.

Future studies could be done by undertaking comprehensive research in understanding why Shariah-compliant funds have expanded in popularity only recently, even though the concept was first developed in the late 1960s. For regulators and policy makers, future research can incorporate the policy concerns to mitigate behavioural risks in online financial communication with relevance to online investing including issues related to managing personal finance and investing. Future research could also look into the emotional aspects among investors because most of them have a lot of prior beliefs before any action especially if they want to purchase online shares as an investment.

\section{References}

Ajzen, I., \& Fishbein, M. (1980). Understanding Attitudes and Predicting Social Behaviour. Englewood Cliffs, NJ: Prentice Hall.

Al-Yahyaee, K. H., Mensi, W., Rehman, M. U., Vo, X. V., \& Kang, S. H. (2020). Do Islamic stocks outperform conventional stock sectors during normal and crisis periods? Extreme comovements and portfolio management analysis. Pacific-Basin Finance Journal, 60 (2020), 101385.

Albert, N., Merunka, D., \& Valette-Florence, P. (2009). The feeling of love toward a brand: concept and measurement. Advances in Consumer Research, Association for Consumer Research, 36, 300-307.

Almansour, A., Ongena, S. (2018). Bank loan announcements and religious investors: Empirical evidence from Saudi Arabia. Journal of Empirical Finance, 47, 78-89.

Amaro, S., Andreu, L., \& Huang, S. (2017). Generation Y travellers' intentions to book Airbnb accommodation: An abstract. In Marketing at the Confluence between Entertainment and Analytics (pp. 43-44). Springer, Cham. 
INTERNATIONAL JOURNAL OF ACADEMIC RESEARCH IN BUSINESS AND SOCIAL SCIENCES

Vol. 10, No. 9, 2020, E-ISSN: 2222-6990 @ 2020 HRMARS

Antar, M., \& Alahouel, F. (2020). Co-movements and diversification opportunities among Dow Jones Islamic indexes. International Journal of Islamic and Middle Eastern Finance and Management, 13(1), 94-115.

Argenti, P. A., \& Barnes, C. M. (2009). Digital strategies for powerful corporate communications. New York, NY: McGraw-Hill.

Chang, M. K. (1998). Predicting unethical behaviour: A comparison of the theory of reasoned action and the theory of planned behaviour. Journal of Business Ethics, 17(16), 1825-1834.

Chauhan, K., \& Pillai, A. (2013). Role of Content Strategy in Social Media Brand Communities: A Case of Higher Education Institutes in India. Journal of Product \& Brand Management, 1(22), 4051.

Chin, W. W. (1998). The partial least squares approach to structural equation modelling. In G.A Marcoulides (Ed.). Modern Methods for Business Research. Mahwah, New Jersey: Lawrence Erlbaum Associates.

Chu, S. C., \& Kim, Y. (2011). Determinants of Consumer Engagement in Electronic Word-of-Mouth (EWOM) in Social Networking Sites. International Journal of Advertising, 30(1), 47-75.

Cohen, J. (1988). Statistical power analysis for the behavioural sciences. (2 ${ }^{\text {nd }}$ Ed.). Hillsdale, NJ: Lawrence Earlbaum Associates.

Daugherty, T., Eastin, M., \& Bright, L. (2008). Exploring Consumer Motivations for Creating UserGenerated Content. Journal of Interactive Advertising, 8(2),16-25.

Demont, L., Kempf, A., Rapidel, M., \& Scibetta, C. (2000). Communication des Entreprises Strate'gies et Pratiques. Nathan.

Department of Statistics Malaysia. (2017). Press Release ICT Use and Access by Individuals and Households Survey Report, Malaysia, https://www.dosm.gov.my/v1/index.php?r=column/pdfPrev\&id=bHBzbWxkWElxRDImaU81 Q3R2ckRkZz09

Formankova, S., Trenz, O., Faldik, O., Kolomaznik, J., \& Sladkova, J. (2019). Millennials' Awareness and Approach to Social Responsibility and Investment-Case Study of the Czech Republic. Sustainability, 11(2), 504.

Fu, J. R., Ju, P. H., \& Hsu, C. W. (2015). Understanding why consumers engage in electronic word-ofmouth communication: Perspectives from theory of planned behavior and justice theory. Electronic Commerce Research and Application, 14(6), 616-630.

Gao, H., Yu, T., \& Cannella, A. A. (2016). The Use of Public Language in Strategy: A Multidisciplinary Review and Research Agenda. Journal of Management, 42(1), 21-54.

Glaser, M., Noth, M., \& Weber, M. (2004). "Behavioural finance", in Koehler, D.J. and Harvey, N. (Ed). Blackwell Handbook of Judgment and Decision Making. Blackwell. Oxford.

Gold, A. H., Malhotra, A., \& Segars, A. H. (2001). Knowledge Management: An Organizational Capabilities Perspective. Journal of Management, 18(1), 185-214.

Han, C. M., \& Guo, C. (2018). How consumer ethnocentrism (CET), ethnocentric marketing, and consumer individualism affect ethnocentric behaviour in China. Journal of Global Marketing, 31(5), 324-338.

Hansen, T., Jensen, J. M., \& Solgaard, H. S. (2004). Predicting online grocery buying intention: A comparison of the theory of reasoned action and the theory of planned behavior. International Journal of Information Management, 24(6), 539-550. 
INTERNATIONAL JOURNAL OF ACADEMIC RESEARCH IN BUSINESS AND SOCIAL SCIENCES Vol. 10, No. 9, 2020, E-ISSN: 2222-6990 @ 2020 HRMARS

Hazari, S., Bergiel, B. J., \& Sethna, B. N. (2017). 'Hedonic and utilitarian use of user-generated content on online shopping websites'. Journal of Marketing Communications. http://www.dx.doi.org/10.1080/13527266.2016.114338

Hudson, S., Huang, L., Roth, M. S., \& Madden, T. J. (2015). The Influence of Social Media Interactions on Consumer-Brand Relationships: A Three-Country Study of Brand Perceptions and Marketing Behaviours. International Journal of Research in Marketing, 33, 27-41.

Hudson, S., Roth, M. S., Madden, T. J., \& Hudson, R. (2014). The Effects of Social Media on Emotions, Brand Relationship Quality, and Word of Mouth: An Empirical Study of Music Festival Attendees. Tourism Management, 47, 68-76.

Hulland, J., Baumgartner, H., \& Smith, K. M. (2017). Marketing survey research best practices: evidence and recommendations from a review of JAMS articles. Journal of the Academy of Marketing Science. 1-17. DOI: 10.1007/s11747-017-0532-y.

Keller, K. L., \& Lehmann, D. R. (2006). Brands and branding: Research findings and future priorities. Marketing science, 25(6), 740-759.

Kietzmann, J. H., Hermkens, K., McCarthy, I. P., \& Silvestre, B. S. (2011). Social media? Get serious! Understanding the functional building blocks of social media. Business horizons, 54(3), 241251.

Knott, A. M. (2003). The organizational routines factor market paradox. Strategic Management Journal, 24(10), 929-943.

Kumar, A., Bezawada, R., Rishika, R., Janakiraman, R., \& Kannan, P. K. (2016). From Social to Sale: The Effects of Firm-Generated Content in Social Media on Customer Behaviour. Journal of Marketing, 0(1), 7-25.

Lee, Y. C. (2017). Effects of branded e-stickers on purchase intentions: the perspective of social capital theory. Telematics and Informatics, 34(2017), 397-411.

Li, C., \& Bernoff, J. (2011). Groundswell: Winning in a World Transformed by Social Technologies. Boston, MA: Harvard Business Review Press.

Li, Y., Fu, H., \& Huang, S. (2015). Does conspicuous decoration style influence customer's intention to purchase? the moderating effect of CSR practices. International Journal of Hospitality Management, 51(2015), 19-29.

Manap, K. H. A., \& Adzharudin, N. A. (2013). The Role of UGC (UGC) in Social Media for Tourism Sector. In West East Institute International Academic Conference Proceedings (pp. 52-58). Istanbul, Turkey.

Miller, T., \& Triana, M. D. C. (2009). Demographic diversity in the boardroom: Mediators of the board diversity firm performance relationship. Journal of Management Studies, 46, 755-786.

Moore, G. C., \& Benbasat, I. (1996). Integrating diffusion of innovations and theory of reasoned action models to predict utilization of information technology by end-users. In Diffusion and adoption of information technology. Springer, Boston, MA.

Muradoglu, G., \& Harvey, N. (2012). Behavioural finance: the role of psychological factors in financial decisions. Review of Behavioural Finance, 4(2), 68-80.

Olson, J., \& Mitchel, A. (1981). Are Product Attribute Beliefs the Only Mediator of Advertising Effects on Brand Attitude? Journal of Marketing Research 18(8), 318-332.

Alahkam, O. F.A. (2016). Performance of shariah-compliant firms and non-shariah compliant firms in the MENA region: Which is better?", Journal of Islamic Accounting and Business Research, 7(4), 268-281. 
INTERNATIONAL JOURNAL OF ACADEMIC RESEARCH IN BUSINESS AND SOCIAL SCIENCES

Vol. 10, No. 9, 2020, E-ISSN: 2222-6990 @ 2020 HRMARS

Palmieri, R., \& Palmieri, C. (2012). Text types, activity types and the genre system of financial communication. In L. Gautier (ed.), Les discoures de la bourse et de la finance. Forum Für Fachsprachen-Forschung [Stock exchange and finance discourses. Forum for research in technical languages] (pp. 85-105). Berlin, Germanu: Frank und Timme.

Palmieri, R., Perrin, D., \& Whitehouse, M. (2018). The Pragmatics of Financial Communication. Part 1: From Sources to the Public Sphere. International Journal of Business Communication, 55(2), 127-134

Podsakoff, P. M., MacKenzie, S. B., Lee, J. Y., \& Podsakoff, N. P. (2003). Common method biases in behavioral research: A critical review of the literature and recommended remedies. Journal of Applied Psychology, 88(5), 879-903.

Praditbatuga, P. (2018). Reaching the Decision to Purchase a Franchise in Thailand. AU Journal of Management, 4(2), 42-50.

Prahalad, C. K., \& Ramaswamy, V. (2004). Co-creation experiences: the next practice in value creation. Journal of Interactive Marketing, 18(3), 5-14.

Preacher, K. J., \& Hayes, A. F. (2008). Asymptotic and Resampling Strategies for Assessing and Comparing Indirect Effects in Multiple Mediator Models. Behaviour Research Methods, 40(3), 879-891.

Ramayah, T., Cheah, J., Chuah, F., Ting, H., \& Memon, M. A. (2018). Partial Least Squares Structural Equation Modelling (PLS-SEM) using SmartPLS 3.0: An Updated Guide and Practical Guide to Statistical Analysis ( $2^{\text {nd }}$ Ed.). Kuala Lumpur, Malaysia: Pearson.

Ramazan, Yildirim, Masih, M., \& Bacha, O. I. (2018). Determinants of capital structure: evidence from Shari'ah compliant and non-compliant firms. Pacific-Basin Finance Journal, 51, 198-219

Reiter, L., \& Connell, K. H. (2017). US Consumers' Environmentally Sustainable Apparel Purchase Intention: Investigating the Role of Social Influence of Peers to Use Social Networking Sites Applied to the Theory of Reasoned Action (An Abstract). In: Rossi P. (Ed) Marketing at the Confluence between Entertainment and Analytics. Developments in Marketing Science: Proceedings of the Academy of Marketing Science. Springer, Cham. https://doi.org/10.1007/978-3-319-47331-4_279

Saadaoui, F. (2018). Testing for multifractality of Islamic stock markets. Physica A: Statistical Mechanics and its Applications, 496, 263-273.

Salleh, N. M., Ariff, M. S. M., Zakuan, N., Sulaiman, Z., \& Saman, M. Z. M. (2016). Attitudinal Factors Affecting Viral Advertising Pass-On Behaviour of Online Consumers in Food Industry. IOP Conference Series: Materials Science and Engineering, 131(1), 12013-12022.

Sanders, W. G., \& Hambrick, D. C. (2007). Swinging for the fences: The effects of CEO stock options on company risk taking and performance. Academy of Management Journal, 50(5), 10551078.

Schivinski, B., \& Dabrowski, D. (2014). The Effect of Social Media Communication on Consumer Perceptions of Brands. Journal of Marketing Communications. DOI:

10.1080/13527266.2013.871323

Securities Commission Malaysia. (2020). List of Shariah-compliant Securities by the Shariah Advisory Council Securities Commission Malaysia.

https://www.sc.com.my/api/documentms/download.ashx?id=dd80630a-6dd5-45ae-bedb$75 f 0586 \mathrm{fe} 3 \mathrm{ec}$

Shimp, T. A., \& Kavas, A. (1984). The theory of reasoned action applied to coupon usage. Journal of 
INTERNATIONAL JOURNAL OF ACADEMIC RESEARCH IN BUSINESS AND SOCIAL SCIENCES

Vol. 10, No. 9, 2020, E-ISSN: 2222-6990 @ 2020 HRMARS

Consumer Research, 11(3), 795-809.

Snell, S. A., \& Dean, J. W. (1992). Integrated Manufacturing and Human Resource Management: A Human Capital Perspective. The Academy of Management Journal, 35(3), 467-504.

Spence, M. (2002). Signalling in retrospect and the informational structure of markets. American Economic Review, 92, 434-459.

Su, L., \& Hsu, M. K. (2013). Service fairness, consumption emotions, satisfaction, and behavioural intentions: The experience of Chinese heritage tourists. Journal of Travel \& Tourism Marketing, 30(8), 786-805.

The Edge Markets. (2018). Bursa FY18 trading volume seen to improve by some $9 \%$. http://www.theedgemarkets.com/article/bursa-fy18-trading-volume-seen-improve-some-9

The Edge. (2018). Shariah Investing Fair 2018 gets 11,000 visitors. http://www.theedgemarkets.com/article/shariah-investing-fair-2018-gets-11000-visitor

The Malaysian Reserve. (2018). Bursa Malaysia looks to retail, foreign investors for further value. https://themalaysianreserve.com/2018/02/06/bursa-malaysia-looks-retail-foreign-investorsvalue/

The Star Online. (2017). More young investors entering into Malaysian market. https://www.thestar.com.my/business/business-news/2017/05/03/younginvestors/\#dA4KY68WZyrsWG9T.99

The Star Online. (2017). Survey shows young Malaysians prefer security over flexibility. http://www.thestar.com.my/news/nation/2016/06/23/youths-want-9to5-jobs-surveyshows-young-malaysians-prefer-security-over-flexibility/

Vallen, T. (2014). How communication becomes the key to financial strength. http://www.mosaichub.com/resources/download/how-communication-becomes-the-keyto-financial-str

VanMeter, R. A., Grisaffe, D. B., \& Chonko, L. B. (2015). Of "Likes" and "Pins": The Effects of Consumers' Attachment to Social Media. Journal of Interactive Marketing, (32), 70-88.

De Villiers, V. M., Visnenza, A., \& Phiri, N. (2017). Importance of location and product assortment on flea market loyalty, The Service Industries Journal, DOI:10.1080/02642069.2017.1410541.

Vernuccio, M. (2014). Communicating corporate brands through social media: An exploratory study. International Journal of Business Communication, 51(3), 211-233.

Wang, A. (2013). Financial Communications, Information Processing, Media Integration, and Ethical Considerations. New York. Palgrave Macmillan.

Wang, S. J. (2018). Using Signalling Theory to Understand the Impact of Information Disclosure on Online Consulting Service Growth. Master Thesis. Information Management, National Sun Yat-sen University.

Wiertz, C., \& de Ruyter, K. (2007). Beyond the call of duty: Why customers contribute to firm-hosted commercial online communities. Organization studies, 28(3), 347-376. 